\title{
Quantum Movement Technique versus William Flexion Exercise on Pain and Walking Ability in Patients with Low Back Pain
}

\author{
${\text { Djohan } \text { Aras }^{1 *} \text {, Nur Asmi }}^{2}$, Yudi Hardianto ${ }^{2}$, Rabia Rabia $^{2}$, Anwar Mallongi $^{3}$ \\ ${ }^{1}$ Department of Physiotherapy, Faculty of Nursing, Hasanuddin University, Makassar, Indonesia; ${ }^{2}$ Bachelor Program in \\ Physiotherapy, Faculty of Nursing, Hasanuddin University, Makassar, Indonesia; ${ }^{3}$ Department of Environmental Health, Faculty \\ of Public Health, Hasanuddin University, Makassar, Indonesia
}

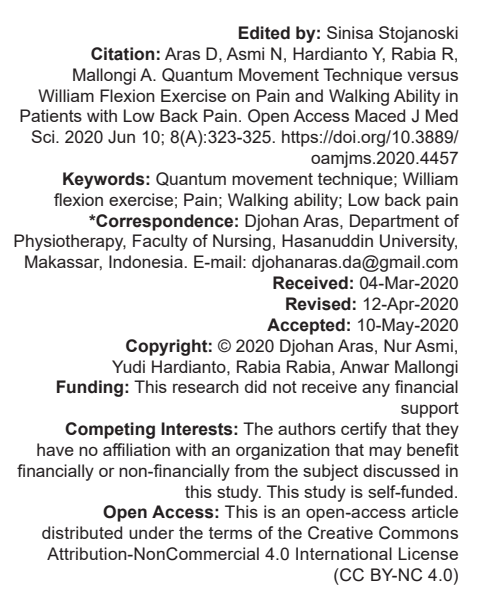

Abstract

OBJECTIVE: Our study aimed to compare between quantum movement technique (QMT) and William flexion exercise (WFE) in patients with low back pain (LBP) based on pain and walking ability.

METHODS: Six-session QMT and WFE were provided for two groups of participants. The frequency of intervention was 6 times/week. Twenty patients (aged 25-65 years) with LBP were randomly assigned into the QMT group $(n=10)$ or the WFE group $(n=10)$. The primary outcome of the intervention was pain, measured using the numeric pain rating scale, while the secondary outcome was walking ability, measured using the Oswestry Disability Index. The measurements were conducted at baseline and the end of the intervention.

RESULTS: Pain reduction was significantly shown in both groups $(p<0.05)$. However, QMT was shown more effective in reducing pain compared to WFE $(p<0.05)$. In addition, we found the significant improvement of walking ability in both groups following the intervention $(p<0.05)$, but no significant difference was shown between two groups $(p>0.05)$.

CONCLUSIONS: QMT is more effective than WFE for reducing pain in patients with LBP.

\section{Introduction}

Low back pain (LBP) is the pain experienced in the lower back. LBP is not only including pain but also muscle spasm of the lower back, which results in muscle imbalance, thus leads to the decrease of abdominal stability and restriction of lumbar mobility [1]. The study conducted by Kalangi et al. [2] revealed that pain, muscle spasm, and the impairment of walking ability were experienced in patients with LBP. The walking speed in patients with chronic LBP was observed much better compared to the patients with subacute LBP. Therefore, LBP can impair the walking ability.

Various interventions were explored to overcome the impact of LBP [3], [4], [5], [6]. Exercise therapy, such as William flexion exercise (WFE), plays a role in pain reduction and improvement of lower back stability by activating the abdominal muscle, gluteus maximus, and hamstring [7]. The other modalities currently developed are quantum movement technique (QMT). QMT is the combination of various techniques such as lumbar extension, stability exercise, nerve mobilization, proprioceptive neuromuscular facilitation (PNF), and neuromuscular therapy [8]. On the other hand, WFE is a technique involving static, passive, and dynamic strengthening exercises and friction. It plays a role in facilitation of flexor group, back pain alleviation, and muscle relaxation, as well as strengthening of the abdominal muscle to gain core muscle stability [9], [10]. Therefore, in the present study, we aimed to compare the effectivity between QMT and WFE on pain and walking ability in patients with LBP.

\section{Materials and Methods}

\section{Study designs}

The study design was a randomized controlled trial. The study protocol was approved by the Ethics Committee of Medical Faculty, Hasanuddin University, Makassar. 


\section{Participants}

Twenty patients with LBP were enrolled in this study. The inclusion criteria were as follows: (1) Patients with LBP, (2) agreed to be included in the present study, (3) age of 25-65 years, and (4) having pain and limitation of activity daily living. The exclusion criteria were as follows: (1) Having LBP due to spondylolisthesis, lumbar compression fracture, malignancy, spinal deformity, acute inflammation, and infection, (2) prescribed with analgesia medication, and (3) not engaging in all study procedures. Before starting the intervention, the study procedures were explained to the participants, and the informed consent was obtained.

\section{Interventions}

Both QMT and WFE were conducted for six sessions. Each session was provided once a day. In each session, the interventions were provided in three repetitions. The intervention durations were $30 \mathrm{~min}$ in each session. QMT is a specific technique of physiotherapy which is modifying and combining various technologies such as neuromuscular technique (NMT), manual therapy, Bugnet exercise technique, McKenzie technique, PNF technique, and Mona's exercise technique. Meanwhile, WFE consisted of five kinds of movements, began with supine position and flexion of both knees. The details of both interventions were provided in supplementary files.

\section{Outcomes}

Before and after the intervention, the walking ability and the pain intensity were measured by the Oswestry Disability Index (walking section) and numeric pain rating scale $(0-2=$ no pain, $3-4=$ mild pain, $5-6=$ moderate pain, $7-8=$ severe pain, and $9-10=$ very severe pain), respectively.

\section{Statistical analysis}

The independent t-test was used to compare the effect of both interventions on the outcomes, while the paired t-test was used to determine whether the outcome changes were affected by the intervention. Statistical analysis was performed using the statistical software SPSS version 22.

\section{Results}

In the present study, we compared the effectivity of QMT to WFE on pain and walking ability in patients with LBP. The characteristics of the participants in this study are shown in Table 1. In the present study,
Table 1: The baseline characteristics of participants

\begin{tabular}{lll}
\hline Characteristic & QMT & QMT \\
\hline Gender & & \\
$\quad$ Male & 4 & 5 \\
$\quad$ Female & $55.9 \pm 9.9$ & $51.9 \pm 12.8$ \\
Age (years)/mean $\pm S D$ & & \\
Waist-to-hip ratio & 2 & 2 \\
$\quad$ Male $<0.95$ & 2 & 3 \\
Male $>0.95$ & 0 & 1 \\
Female $<0.80$ & 6 & 4 \\
$\quad$ Female $>0.80$ &
\end{tabular}

we revealed that significant differences in pain intensity and walking ability were shown after the interventions in both groups $(p<0.05)$. Moreover, the pain changes were significantly higher in individuals treated with QMT than WFE. However, the walking ability changes were similar between the two groups $(p>0.05)$ (Table 2).

\section{Discussion}

The main finding of the present study was that the improvement of pain was observed higher in the QMT group compared to the WFE group. However, the pain reduction was also significantly observed in WFE. WFE focuses on the strengthening of abdominal muscles, gluteus maximus, and the stretching of back extensors. The stretching of back extensors can improve the range of motion, increase the local temperature, and improve the muscle metabolism. Hence, the metabolic waste products can easily be removed [11]. The strengthening of the abdomen muscle also helps to support the spine; thus, the ligament of the spine stay aligned [12]. Various movement of WFE has an impact on the activation of the abdominal muscle, gluteus maximus, and hamstring, in addition to the passive stretching of hip flexors and lower back muscles; therefore, the muscle balance between flexor group and extensor group of the postural group can develop. The positive impact of WFE can lead to a decrease of stress on posterior aspects of lumbar as well as the strengthening of abdominal muscle and gluteus maximus which results in pain reduction of lower back and improving the activity daily living. WFE also may improve the flexibility/elasticity in hip flexor group and lower back (sacrospinalis) and restore the balance between postural flexor and extensor group [7].

On the other hand, QMT is the modified technique developed based on research to treat the impairment of movement and function. The combination between lumbar extension and mechanical traction has been proven in reducing the pain and improving the functional activity. Lumbar stabilization exercise also contributes to pain reduction and improvement of functional activity, as well as increase of the mobility and stability of sacroiliac joint in patients with herniated nucleus pulposus (HNP) [13]. The exercise also improves the restoration in patients with HNP, in addition to improving the proprioceptive function. The 
Table 2: Outcomes in both intervention groups

\begin{tabular}{|c|c|c|c|c|c|c|c|}
\hline \multirow[t]{2}{*}{ Outcomes } & \multicolumn{3}{|l|}{ QMF } & \multicolumn{3}{|l|}{ WFE } & \multirow[t]{2}{*}{$p$ value for difference between groups } \\
\hline & Pre & Post & $\mathrm{p}$ value & Pre & Post & $p$ value & \\
\hline Pain & $8.80 \pm 1.135$ & $3.10 \pm 0.876$ & 0.004 & $7.10 \pm 0.876$ & $4.0 \pm 0.943$ & 0.004 & 0.000 \\
\hline Walking ability & $3.30 \pm 0.675$ & $1.70 \pm 0.675$ & 0.004 & $3.10 \pm 0.738$ & $1.80 \pm 0.789$ & 0.004 & 0.313 \\
\hline
\end{tabular}

combination between nerve mobilization and abdominal strengthening using PNF was shown to improve the pain and the functional activity in patients with chronic LBP [14]. The underlying mechanism of QMT is that the improvement of nerve mobility and muscle flexibility leads to the pain reduction, while the core stability functions to increase the stabilization of abdominal and spinal. In addition, NMT decreases pain and improves the flexibility of soft tissue [8], [12], [15], [16].

\section{Conclusions}

Based on the findings in the present study, we concluded that QMT is more effective than WFE for reducing pain in patients with LBP. While for walking ability, the similar effects between QMT and WFE were observed.

\section{References}

1. Andini F. Risk factors of low back pain in workers. Med $J$ Lampung Univ. Available from: http://www.juke.kedokteran. unila.ac.id/index.php/majority/article/view/495. [Last accessed on 2019 Sep 27].

2. Kalangi P, Angliadi E, Gessal J. Perbandingan kecepatan berjalan pada pasien nyeri punggung bawah mekanik subakut dan kronik menggunakan timed up and go test. J E-Clinic (ECL). 2015;3(1):143-9. https://doi.org/10.35790/ecl.3.1.2015.6755

3. Shipton EA. Physical therapy approaches in the treatment of low back pain. Pain Ther. 2018;7(2):127-37. https://doi.org/10.1007/ s40122-018-0105-x

PMid:30229473

4. Jeong DK, Choi HH, Kang JI, Choi H. Effect of lumbar stabilization exercise on disc herniation index, sacral angle, and functional improvement in patients with lumbar disc herniation. J Phys Ther Sci. 2017;29(12):2121-5. https://doi.org/10.1589/ jpts.29.2121

PMid:29643588

5. Castro-Sánchez AM, Lara-Palomo IC, Matarán-Peñarrocha GA, Fernández-De-Las-Peñas $\quad C$, Saavedra-Hernández $M$, Cleland J, et al. Short-term effectiveness of spinal manipulative therapy versus functional technique in patients with chronic nonspecific low back pain: A pragmatic randomized controlled trial. Spine J. 2016;16(3):302-12. https://doi.org/10.1016/j. spinee.2015.08.057

PMid:26362233

6. Balthazard P, De Goumoens P, Rivier G, Demeulenaere P, Ballabeni $P$, Dériaz $O$. Manual therapy followed by specific active exercises versus a placebo followed by specific active exercises on the improvement of functional disability in patients with chronic non specific low back pain: A randomized controlled trial. BMC Musculoskelet Disord. 2012;13:162. https://doi. org/10.1186/1471-2474-13-162

PMid:22925609

7. UNNES. Keefektifan William Flexion Exercise Untukmengurang Nyeri Punggung Bawah Pada Penjahitpt Argo Manunggal Triasta Kota Salatiga Tahun. Indonesia: UNNES; 2016.

8. Aras $\mathrm{D}$, Ahmad $\mathrm{H}$. The efficacy of physiotherapy combination technique on pain and functional independence of people with lumbar disc herniation: (Physiotherapy combination technique: A conservative treatment for lumbar disc herniation) Indian J Public Health Res Dev. 2018;9(8):1524-9. https://doi. org/10.5958/0976-5506.2018.00949.x

9. Jeganathan A, Kanhere A, Monisha R. A comparative study to determine the effectiveness of the mckenzie exercise and williams exercise in mechanical low back pain. Res J Pharm Technol. 2018;11(6):2440. https://doi. org/10.5958/0974-360x.2018.00450.x

10. Fatemi R, Javid M, Najafabadi EM. Effects of William training on lumbosacral muscles function, lumbar curve and pain. J Back Musculoskelet Rehabil. 2015;28(3):591-7. https://doi. org/10.3233/bmr-150585

\section{PMid:25736954}

11. Thomas E, Bianco A, Paoli A, Palma A. The relation between stretching typology and stretching duration: The effects on range of motion. Int J Sports Med. 2018;39(4):243-54. https:// doi.org/10.1055/s-0044-101146

PMid:29506306

12. Kim BR, Lee HJ. Effects of proprioceptive neuromuscular facilitation-based abdominal muscle strengthening training on pulmonary function, pain, and functional disability index in chronic low back pain patients. J Exerc Rehabil. 2017;13(4):48690. https://doi.org/10.12965/jer.1735030.515

PMid:29114517

13. Coulombe BJ, Games KE, Neil ER, Eberman LE. Core stability exercise versus general exercise for chronic low back pain. J Athl Train. 2017;52(1):71-2. https://doi. org/10.4085/1062-6050-51.11.16

PMid:27849389

14. Krekoukias G, Gelalis ID, Xenakis T, Gioftsos G, Dimitriadis Z, Sakellari V. Spinal mobilization vs conventional physiotherapy in the management of chronic low back pain due to spinal disk degeneration: A randomized controlled trial. J Man Manip Ther. 2017;25(2):66-73. https://doi.org/10.1080/10669817. 2016.1184435

PMid:28559665

15. Franca FR, Burke TN, Hanada ES, Marques AP. Segmental stabilization and muscular strengthening in chronic low back pain-a comparative study. Clinics. 2010;65(10):1013-7. https:// doi.org/10.1590/s1807-59322010001000015

PMid:21120303

16. Lee CW, Hwangbo K, Lee IS. The effects of combination patterns of proprioceptive neuromuscular facilitation and ball exercise on pain and muscle activity of chronic low back pain patients. J Phys Ther Sci. 2014;26(1):93-6. https://doi.org/10.1589/ jpts.26.93 PMid:24567683 